\title{
REVIEW
}

\section{European intertidal marshes: a review of their habitat functioning and value for aquatic organisms}

\author{
A. Cattrijsse ${ }^{1, *}$, H. Hampel ${ }^{2}$ \\ ${ }^{1}$ Flanders Marine Institute - VLIZ, Wandelaarkaai 7, 8400 Oostende, Belgium \\ ${ }^{2}$ Royal Belgian Institute for Natural Sciences, Vautierstraat 29, 1000 Brussels, Belgium
}

\begin{abstract}
Salt marshes form true ecotones between land and sea fauna and flora that have adapted to an environment that is both aquatic and terrestrial in nature. Despite the extreme and sharp gradients that exist in salt marshes, they form the temporary or permanent home for many animals and plants and they fulfil many important roles in marine and estuarine ecosystems. While research on the terrestrial component of European marshes has helped in their management, knowledge of the aquatic component has largely been ignored in safeguarding the existence and ecological importance of tidal marshes. This situation is in sharp contrast with studies of coastal marshes along the eastern and southeastern coasts of North America. The typical European salt marsh differs in several physical aspects from the typical American salt marsh, but recent investigations have indicated parallels regarding nekton habitat usage. The present paper reviews the current state of European studies on the habitat role that tidal marshes play for fish and crustacean fauna. Mirrored against the more extensive American literature, we discuss where functional similarities and differences exist between both types of tidal marshes and where further knowledge is still needed for European marshes. Management of European tidal marshes would benefit from extending the current knowledge, and this paper identifies potential topics of interest.
\end{abstract}

KEY WORDS: European tidal marsh $\cdot$ Estuarine systems $\cdot$ Nekton $\cdot$ Habitat functioning

\section{INTRODUCTION}

Since the late 1960s scientists have shown interest in the ecology of tidal marshes. Teal (1962) wrote one the first leading papers on the subject. His investigation dealt with fluxes of organic matter and inorganic nutrients between salt marshes and coastal environments. His ideas on the ecological functioning of tidal marshes became a standard with which all other studies were compared. Later, scientists started to study different aspects of tidal marsh functioning in estuarine and coastal ecosystems.

Salt marshes are defined as areas with alluvial sediments deposited on the shore by the sea and subjected to tidal or weather-effected inundation by more or less diluted seawater. The moisture conditions of the soil vary from continuously waterlogged to at least tem- porarily moist, and plant communities, consisting completely or predominantly of halophytes, occupy the soils (Beeftink 1977). Salt marshes occur on intertidal shores in mid- and high-latitude regions worldwide (Kennish 2001), since mangroves, which dominate the tropical zones, cannot survive temperatures below $-4^{\circ} \mathrm{C}$.

The role that tidal marshes play as habitats for fish has been studied intensively since the 1970s (e.g. Cain \& Dean 1976). The first studies dealt with American tidal marshes that stretch over vast areas of coastal and estuarine shallow areas along the Atlantic and Gulf coasts. It is now no longer questioned that the presence of tidal creeks and ponds is primordial in the survival of youngof-the-year fish and macrocrustaceans (Kneib 1997a).

On the European continent humans have reclaimed large intertidal vegetated ecosystems since the early 
Middle Ages, and estuaries have changed completely due to anthropogenic influences. Some of these activities, like land reclamation or the construction of dikes (Davidson et al. 1991, Mitsch et al. 1994), destroyed vast areas of intertidal wetlands, others changed the functioning of the estuary. Habitat loss through physical removal, the deterioration of quality, or the prevention of use by faunal species pose serious threats along estuaries (Elliott et al. 2002). These processes are still very much present along all European coasts, although conservation attempts have largely put a stop to the reclaiming of marshlands (Cattrijsse et al. 2002). While direct destruction of intertidal marshes is under very strong restrictions nowadays, physical alterations of estuaries still continue and result in loss of intertidal area. The main cause of wetland loss in the future will likely be a rise in the global sea level, threatening all low-lying areas. It is presently scientific consensus that the rise over the next $40 \mathrm{yr}$ will reach $30 \mathrm{~cm}$ (Kerr 1989). In the Rhone and Ebro deltas the sea level rise represents a huge challenge for the protection of coastal habitats (Day et al. 1995).

In Europe, Labourg et al. (1985), Frid (1988) and Frid \& James (1989) initiated the study of aquatic marsh fauna. The later studies of Drake (1991a,b), Costa et al. (1994) and Cattrijsse et al. (1994) were the first indepth studies on the subject. It was clear from the beginning that European marshes differed in some aspects from, but nevertheless functioned quite similar to their American counterparts.

After $20 \mathrm{yr}$ of studies, we present a review here of the main findings of European marsh nekton research, supported by the broader and more numerous studies concerning US marshes. In the first section, we briefly describe the European salt marsh habitat and point at general differences (tidal regime, vegetation, fate of primary production and habitat structure) with North American marshes. The second section summarises the main nekton species present in northern and southern European marshes. In the third section, the known feeding habits of the main nektonic species are reviewed. The fourth and main section focuses on the functioning of European marshes, putting 7 questions forward and highlighting the topics that remain unanswered. These questions present different, sometimes conflicting views, thus indicating future topics in European marsh research. The last chapter discusses where marsh nekton research can feed into current tidal marsh management issues.

\section{THE EUROPEAN SALT MARSH HABITAT}

Genuine intertidal marshes transected by meandering creeks only exist along the coasts and in estuaries of the North Sea and the European Atlantic, including the Channel areas and the Irish Seas. In the microtidal Baltic and Mediterranean, shallow marine and brackish lagoons or ponds occur that resemble true salt marshes by nature of their halophyte vegetation. These biotopes may harbour aquatic fauna similar to those found in tidal-creek-structured marshes of the Atlantic and North Sea coasts, but will function differently in many aspects, due to irregular, non-tidal flooding. The term salt marsh generally refers to aquatic systems dominated by halophyte vegetation, but also includes freshwater tidal marshes. Freshwater plants typify oligohaline marshes, but otherwise they function similar to their marine counterparts, due to the same semi-diurnal inundation.

Tidal amplitude, local current patterns and hydrological conditions will determine the flooding frequency of intertidal areas and thus the tidal heights between which vegetation can occur (Beeftink 1977). Extreme high water defines the upper terrestrial limit of salt marsh vegetation. The lower limit is generally defined by the MHWN (mean high water neap tide) on the European continent (Beeftink 1977). This constitutes a major difference with the US Atlantic salt marshes (Cattrijsse et al. 1994), where the lower limit is generally reached around the MTL (mean tide level) (Reimold 1977). The vegetated surface of the US marsh will flood almost every high tide, while the European marsh surface is only inundated during the highest tides. Species migrating to European marshes primarily use the marsh creeks as nursery or foraging grounds. The functionality within a larger ecosystem and the use aquatic organisms can make of the habitat will therefore differ largely at both sides of the Atlantic.

The vegetation of both types of salt marshes also differs essentially (Adam 1990). The North American salt marshes are almost mono-specific stands of Spartina alterniflora. Subdominant species include Spartina patens, Juncus roemerianus and Distichlis spicata (Reimold 1977). Sea purslane Halimione spp. typifies European marshes, but other species also dominate the marsh vegetation: glassworts Salicornia species, cord grass Spartina anglica, sea couch-grass Elymus athericus, common salt marsh grass Puccinellia maritima, seaside bulrush Scirpus maritimus, sea plantain Triglochin maritima, reed Phragmites australis, spearleaved orach Atriplex hastata and/or sea lavender Limonium species (Beeftink 1977).

Stem density is much lower in the American Spartina marshes, leaving plenty of space for small fish to wander around on the marsh surface during high tides. When the highest tides flood European marshes, the dense vegetation inhibits fish or nekton from venturing among the plant stems. After spring tides, small fish 
regularly get trapped amongst the stems when water retreats to channels or pools (authors' pers. obs.).

As American marshes are flooded more often, the bulk of the primary production will finally be washed into the water and be transported to the adjacent subtidal, to end up there as detritus where it forms the basis of the food chain. Only a very small amount is remineralised locally (Teal 1962, Odum \& Heald 1975, Nixon 1980). In European marshes export of organic material is largely absent (Wolff et al. 1979, Beeftink \& Rozema 1988, Hemminga et al. 1992, 1993, Dame \& Lefeuvre 1994). The dead marsh plants decay on the marsh surface and can only get washed into the water during the highest tides (Bouchard \& Lefeuvre 2000).

In European intertidal marshes even the largest creeks drain almost completely during the ebb period, in contrast to American marshes, where subtidal channels hold water at low tide. The shorter migration route and longer foraging period in American intertidally vegetated habitats will also contribute to differences in utilisation of marsh habitat by nekton.

These functional aspects of marsh ecosystems on both continents can, however, not be generalised and will depend on local circumstances like the latitude, tidal amplitude, plant communities and geomorphologic characteristics of each individual system (Dame \& Gardner 1993, Lefeuvre \& Dame 1994, Lefeuvre et al. 1994).

Across European latitudes major coastal and estuarine marshes have been sampled in the UK, The Netherlands, Belgium, France, Spain and Portugal. European research on salt marsh nekton is, however, behind the extended investigations in the United States. Regardless of the fundamental differences between the marshes at both sides of the Atlantic, both types provide nursery areas and foraging grounds for fish and macrocrustaceans. Not all studies performed in US marshes will prove useful for the European case.

Apart from Europe and North America, a limited number of descriptive publications from Australia (Morton et al. 1987, Davis 1988) and South Africa (Paterson \& Whitfield 1996, 2000) are also available. A holistic view of intertidal marsh functioning requires studies from these regions too. Additional descriptive studies of European marsh fauna will still prove rewarding, in further substantiating marsh habitat importance and in determining the role of the physical environment and the present species assemblages. Only a better understanding of the functioning of European salt marshes as habitats for fish or macrocrustaceans may help to protect these rare and valuable habitats. Future studies will need to address these functionalities of the marsh intertidal.

\section{THE FISH AND CRUSTACEAN FAUNA OF EUROPEAN MARSHES}

Labourg et al. (1985) were the first to report on faunal samples collected in the intertidal marshes of the Gironde estuary, SW France. Frid (1988) and Frid \& James (1989) sampled during low tide on the salt marshes of the Wash, UK, and found wandering juvenile shore crabs on the vegetated marsh surface during summer, sand gobies Pomatoschistus minutus, juvenile mullets Chelon labrosus, juvenile flounder Platichthys flesus, juvenile plaice Pleuronectes platessa, prawns Palaemon spp. and brown shrimp Crangon crangon in tidal pools. Previously, Kelley (1986) and Kelley \& Reay (1988) had reported on the occurrence of sea bass Dicentrarchus labrax and other fish in shallow marsh creeks.

In a subtidal channel near Cadiz Bay, SW Spain, Drake \& Arias (1991a) found 39 species in the ichthyoplankton. An identical number of species was found in a 4 yr study in an intertidal channel of the same ecosystem (Drake \& Arias 1991b). Regardless of the relatively low numbers, the shallow environment was acting as an alternative nursery area to estuarine habitats for these species, some commercially important. The marsh-bordered zone of the Mira Estuary, Portugal, on the other hand, was thought to be vital for estuarine fish populations (Costa et al. 1994); 49 species were found to frequent the shallow subtidal areas in front of the estuarine tidal marshes (Costa et al. 2001).

Much like American coastal marshes, European intertidal creeks are, during high tide, inhabited by a lower number of species than the adjacent subtidal waters. Only a limited number of species seem to take advantage of the habitat during flooding. Recently, Salgado et al. (2004a) found 14 fish species in intertidal marsh creeks of the Tagus estuary and 27 species on the mudflats in front of those creeks. In northern Europe, Cattrijsse et al. (1994) found a total of 68 species of fish and crustaceans in an oligohaline marsh of the Westerschelde estuary (SW Netherlands). A total of 20 fish species were caught with a very fine mesh size, but only 6 of these were common. Most of the species present in the estuary were never observed in the marsh (Hostens 2000). Sampling both the small and large individuals of the fish community of the marshes of Mont Saint-Michel, northern France, Laffaille et al. $(1998,2000 a)$ found a total of 31 species, 8 of which were common. Lefeuvre et al. (1999) mentioned that about one-third of the coastal fish community was found to invade marshes. Observations made in SE Portugal, however, contradict the assertion that fewer species use marshes. Vieira et al. (2002) found 33 fish species in the marsh creeks of Castro Marim, while 37 species were found in the Guadiana estuary. 
Using some of the above-mentioned datasets and some unpublished records, Mathieson et al. (2000) compared the fish assemblages of 6 European marsh sites. Taking differences in sampling methodology into account they found that the taxonomic structure of northern and southern sites differed substantially. Analysing ecological guild structures revealed striking functional similarities between all sites, despite the major physical and taxonomical differences that exist among the sites. While some marshes were dominated by pelagic species, others were structured by benthic species. This division of the studied sites was also partly reflected in differences in dietary and vertical distribution guilds.

Depending on site and latitude, species that visit European intertidal marsh creeks regularly and in large numbers include gobies Pomatoschistus microps, P. minutus and Aphia minuta, eel Anguilla anguilla, clupeids Sprattus sprattus, Sardina pilchardus and Engraulis encrassicolus, syngnathids Syngnathus rostellatus and S. acus, sparids Sparus aurata and Diplodus spp., mullets Liza ramada, 3-spined stickleback Gasterosteus aculeatus, seabass Dicentrarchus labrax, and flatfishes Platichthys flesus, Pleuronectes platessa, Solea solea and Solea senegalensis. Eel, flounder and the goby species are the most numerous recorded species for European intertidal marshes (Mathieson et al. 2000). The dominant goby species differ between marine and estuarine marshes: the sand goby Pomatoschistus minutus occurs in marine marshes (Frid 1988, Frid \& James 1989, Laffaille et al. 2000a), while the common goby, an estuarine resident, is the most important fish species in brackish waters (Drake \& Arias 1991a,b, Cattrijsse et al. 1994, Hampel et al. 2003a, Salgado et al. 2004b).

Salgado and colleagues compared the fish assemblage of tidal marsh creeks and adjoining mudflats (Salgado et al. 2004a). They found that only the common goby was a marsh-resident species. Seabass, anchovy and mullets occurred regularly and in high numbers in the creeks, while sand goby and sole remained on the mudflat.

On the occurrence of crustaceans in European marshes little information is available. Common crustacean species include crabs Carcinus maenas, shrimp Crangon crangon and Palaemonetes spp. and mysids Neomysis integer. Shore crabs C. maenas may wander on the marsh surface (Frid \& James 1988), while juvenile brown shrimp $C$. crangon can be found in high densities in tidal pools during low tide (Cattrijsse et al. 1997). Juveniles of both species regularly use intertidal creeks and pools as habitat (Cattrijsse et al. 1997). Palaemonid shrimp have also been recorded from pools (Frid \& James 1989, Hampel et al. 2004). Mysid shrimp occur only in creeks, but sometimes in vast numbers (Cattrijsse et al. 1994, Hampel et al. 2003a).

Most European studies are restricted to marine or estuarine marshes. Freshwater marshes have become a very rare habitat in western Europe. The fish fauna of freshwater marshes has not yet been studied in detail. Hampel et al. (2004) have sampled all along the tidal Schelde River, but found only a very limited number of fish. It is known that the low environmental quality of the river (i.e. critical oxygen concentrations) has low numbers of fish throughout its tidal freshwater reaches (Maes et al. 1997). The habitat function of European reed-and willow-dominated tidal marshes for fish has not been documented.

\section{FEEDING OF FISH AND CRUSTACEANS IN EUROPEAN TIDAL MARSH CREEKS}

Information on diets of feeding fish or crustaceans in European marshes is still largely absent, but the diets of some of the above-mentioned fish species have been examined in a number of studies. The available data show that all fish species foraging regularly in intertidal creeks prey upon similar infauna or invertebrate nekton species. Especially the amphipods Corophium volutator and Orchestia gammarellus, the annelid Nereis diversicolor and the mysid Neomysis integer feature abundantly as prey.

Sea bass is a commercially valuable fish that forages regularly in intertidal marsh creeks (Kennedy \& Fitzmaurice 1972, Kelley 1988, Sá et al. 2002, Hampel et al. 2005). Young of the year of this predatory fish have been found to feed intensively on marsh crustaceans. In Westerschelde marshes, Dicentrarchus labrax preyed upon a wide range of species, but the main prey items were Corophium volutator, Nereis diversicolor, Crangon crangon, Carcinus maenas and Orchestia species (Cattrijsse et al. 1994, Hampel at al. 2005). In Mont Saint-Michel marshes along the coast of Normandy, Laffaille et al. (2000b, 2001a) reported a very similar diet of young sea bass, comprising mainly Orchestia gammarellus, Nereis integer, C. volutator, $N$. diversicolor and copepods. In the northern marshes of the Humber estuary, some of these prey featured equally important in the stomach contents of young sea bass. There, Gardner (1996) reported C. crangon, N. diversicolor, $N$. integer and Sprattus sprattus as the main prey items. Also, in the marshes of the southern European Tagus estuary, the diet of 0-group sea bass was mainly composed of decapods, mysids and isopods (Cabral \& Costa 2001).

The diets of Pomatoschistus minutus and P. microps have also been analysed by the previous authors. Few species were important in the diet of the juvenile com- 
mon gobies in the Westerschelde. Numerically, copepods dominated the diet in spring. Mesopodopsis slabberi, Nereis integer and Corophium volutator were the most dominant prey items in terms of biomass throughout the year (Cattrijsse 1994, Hampel et al. 2005). In the Bay of Mont Saint-Michel, the diet of P. minutus was dominated by Orchestia gammarellus and N. integer (Laffaille et al. 2001a).

In Westerschelde marshes, Platichthys flesus seemed to prey almost exclusively on the 2 most important benthic invertebrate prey: Corophium volutator and Nereis diversicolor (Hampel et al. 2005). The diet of $P$. flesus caught in the Humber marshes comprised mainly $N$. diversicolor, Manayunkia aesturina, Macoma baltica and Crangon crangon (Gardner 1996). Cabral (2000) described the food composition of Solea solea found feeding in the salt marshes of the Tagus, Portugal; this flatfish predominantly preyed upon Polychaeta, mainly N. diversicolor and Amphipoda, particularly Corophium spp. Sá et al. (2002) still observed $C$. crangon as the principal prey during summer in a salt marsh of Castro Marim, Portugal.

Apart from predatory fish species, omnivorous fish may also feed inside intertidal creeks. Mullets frequently visit intertidal marshes. In the marshes of Mont Saint-Michel, Laffaille et al. (2002) found mullets Liza ramada mainly feeding on diatoms, copepods, nematodes and detritus. In the Castro Marim salt marsh of Portugal, all grey mullets Chelon labrosus, Liza aurata, L. ramada, L. saliens and Mugil cephalus fed exclusively on detritus, Crangon crangon, amphipods and Carcinus maenas (Sá et al. 2002).

In US marshes, several researchers observed that the gut fullness of fish and macrocrustaceans increases during residence in the intertidal (Kneib 1997b). European marshes function likewise as foraging grounds for fish and crustaceans. Common goby, seabass, flounder, mullets and common shrimp were all found leaving the marsh habitat during ebb tide with significantly more food in their stomachs. The marsh invertebrate infauna and epifauna thus attract a number of species to venture into the marsh and to forage during higher water levels on the abundant marsh invertebrate communities.

In a mesohaline marsh of the Westerschelde estuary, the tidal cycle strongly influences the migration and the feeding activity of Pomatoschistus microps. Maximum foraging activity coincided with flood tide. Gobies started leaving the marsh with the outgoing tide, and their gut contained significantly more food than when they entered the creek (Hampel \& Cattrijsse 2004). Seabass (Cattrijsse et al. 1994) and juvenile brown shrimp (Cattrijsse et al. 1997) were also found to make tidal foraging excursions into intertidal estuarine marsh creeks.
Lefeuvre et al. (2000) and Laffaille et al. (2001a) also found sea bass to forage intensively in the coastal marshes of Normandy. In the same marsh complex, Laffaille et al. $(1998,1999)$ proved that the gobies Pomatoschistus minutus and P. lozanoi took a significant amount of prey during their marsh residence between flood and ebb tides. Not only carnivorous, but likewise herbivorous/detrivorous fish, find better foraging opportunities in marsh creeks; the instantaneous feeding ration of Liza ramada increases between flood and ebb tides (Laffaille et al. 2002).

Solea species in the Tagus estuary showed a strong relationship between feeding activity and the tidal cycle (Cabral 2000). The decrease in vacuity values during high tide suggests that Solea species use intertidal areas as feeding grounds, as do Platichthys flesus and P. platessa (Gibson 1973, Burrows et al. 1994).

The foraging activity of marsh-feeding fish was found to be more complex than just tidally stimulated. The tidal stimulus seemed to rule out diel differences in the feeding habit of Pomatoschistus microps. Hampel \& Cattrijsse (2004) showed that the feeding intensity was equal during daylight and nocturnal tides. During spring tides, however, these gobies had almost twice as much food in their stomachs upon leaving the creek than during neap tides. During spring tides a diel difference in foraging intensity became pronounced, but disappeared during neap tides (Hampel \& Cattrijsse 2004). The combined effect of lunar and diel influences on foraging intensity remained unanswered.

\section{ECOLOGICAL FUNCTIONING OF EUROPEAN MARSHES}

The interest in the aquatic fauna of intertidal marshes results largely from the idea that intertidal marshes function as important nurseries for fish and crustacean species, some of which are economically important (e.g. Costa et al. 1994, Rozas 1995, Kneib 1997a, Dionne et al. 1999). Nurseries, by definition, offer better growth and survival through optimal foraging (Allen et al. 1994, Craig \& Crowder 2000, Laffaille et al. 2002), refuge (Whitfield 1998, Halpin 2000, Paterson \& Whitfield 2000, Costa et al. 2001), and/or enhanced growth. The value of the marsh habitat for young marsh-visiting individuals is reflected in the capacities of the intertidal marsh to offer food and refuge. For measuring and describing the habitat value, different indicators are used. The density of juveniles reflects recruitment, mortality and emigration; thus, density can be an important indicator of nursery habitat value (Minello 1999). Food availability is probably the major factor determining fish habitat quality (Gibson 1993). 


\section{Are the densities of nursery species higher in marsh creeks?}

In US marshes differences in densities among tidal creeks, seagrass beds and unvegetated habitats have been shown for several species (Orth \& van Montfrans 1990, Rozas \& Minello 1998, Rozas \& Zimmerman 2000). For the European continent, however, no such data are available. The only comparison that has been made between marsh and adjacent subtidal habitats is the study of Salgado et al. (2004a), who showed differences in habitat use, but no differences in abundance. Differences in habitat use are, however, to be expected. Tidal marsh fish assemblages will reasonably bear some similarity with those of nearby subtidal waters. Mathieson et al. (2000) argued that similarity between 6 European marshes and their estuaries was generally greater than amongst the individual marshes.

Some criteria will need to be met before a specific habitat functions as an important nursery area for certain species. Pihl et al. (2002) defined a nursery as an area where juveniles aggregate, temporally or spatially segregated from the adults, and where their survival is enhanced through optimal conditions for feeding, growth, and/or predation refuge. The presence of large numbers of juveniles, even in the complete absence of adult stages, is thus insufficient to nominate a habitat as a nursery. Survival may be equally optimised in other, adjacent habitats.

Beck et al. (2001) define a nursery as we have defined it here, but they add that a habitat only functions as a nursery when, on average, from that habitat more juveniles per unit area recruit to the adult population than from other habitats. According to these authors, the existence of this criterion proves the nursery role.

However, any study supplying such information would prove more than merely the presence of the nursery function. It would also establish the quantitative importance of the area in relation to one or more adjacent areas.

The difficulty in sampling nekton from vegetated marsh or from shallow intertidal creeks while inundated contributes to the fragmentary results of nekton work. A range of sampling methods has been described that varies in portability, size, deployment, escape rates of nekton and expense; none has yet become standard (Connolly 1999). Sampling in fundamentally different habitats requires fundamentally different techniques (Kneib 1997b, Rozas \& Minello 1997). Intertidal creeks are mostly too shallow and too small for trawling, which is generally the standard technique for sampling small-sized epifauna or nekton in soft-sediment environments. Fyke nets, block nets, or any other types of passive gear are mostly unsuit- able for gathering representative occurrence or abundance data in the subtidal (Rozas \& Minello 1997). Different subtidal habitats (seagrass, unvegetated bottom) influence nekton distribution and further contribute to sampling difficulties (Irlandi \& Crawford 1997).

Certainty about abundance differences in European tidal creeks and the adjacent subtidal shallows will remain very difficult to obtain and might necessitate sampling techniques other than those considered standard to date. Further, estimating densities in both subtidal and intertidal creeks will not compensate for tidal migrations. One might argue that, even with a comparable technique, a bias would remain if the observations in the intertidal were made during the highest water levels. It is well known that fish tend to concentrate in shallow subtidal areas awaiting the next flood tide, to wander over the intertidal to feed or seek temporal refuge from predators. At low water, densities in the shallow subtidal might thus be as high as the densities in the creeks during high water, where all those young individuals concentrate again to take advantage of the food abundance and complexity of the habitat. Kneib \& Wagner (1994) and Cattrijsse et al. (1994) have shown that fish tend to follow the edge of the tide to migrate between the intertidal and subtidal. Such tidal migrations cause a spatial shift in the assemblage, possibly making the discussion on differences in abundance between both habitats futile. Only estimates of what proportion of a species population migrates to the marsh intertidal will define the quantitative importance of intertidal creeks for that species.

Seasonal shifts in habitat use mark the importance of intertidal marsh habitats more clearly than spatial differences in abundance. Spatial shifts in the occurrence of a species between adjacent habitats may prove that the individuals select certain environments during the successive developmental stages of their early life. In the Westerschelde, young-of-the-year sea bass reach a maximum abundance in the marshes (Cattrijsse et al. 1994) some months before their densities peak on the intertidal flats in front of those marshes (Hostens 2003). The main differences Salgado et al. (2004a) described were also related to temporal abundance fluctuations of the dominant species and seasonal ingress of nursery species.

\section{Are prey abundances higher and foraging opportunities better in salt marsh creeks?}

It is generally accepted that, despite the variable environment, tidal marshes are used extensively because of their high productivity, providing enhanced foraging opportunities for juvenile fish and macrocrus- 
taceans (Boesch \& Turner 1984). Due to the high productivity of salt marshes, creek sediments contain a higher nutrient load, attracting large numbers of detritus-feeding organisms that act as primary prey for foraging fish (Laffaille et al. 2002). Higher detritus biomass in the upper layer also coincided with higher densities of detrivorous or omnivorous benthic species (Netto \& Lana 1997).

Comparing infauna between marsh creeks and intertidal flats in front of marsh systems may supply arguments in favour of this hypothesis, even though prey abundance is not equal to prey availability. Fish would thus enter tidal creeks to profit from local prey abundance. In the Westerschelde estuary, infauna prey densities of both the intertidal creeks and intertidal flats largely fell within similar ranges. The average total abundance of the macrobenthic species in marsh creeks in early autumn reached $10218 \pm$ 2524 ind. $\mathrm{m}^{-2}$ (Hampel 2003). This figure was lower than the values reported for the intertidal flat by Ysebaert et al. (1993) and Ysebaert \& Herman (2002). However, lower values were found for the intertidal flat when analysing a dataset from 1978 to 1997 (Ysebaert et al. 2000) compared to the values for the intertidal marsh creek (Hampel 2003). The density of one of the main benthic prey species, Nereis diversicolor, was higher in the marsh creeks (Hampel 2003) than on the intertidal flats (Ysebaert \& Herman 2002).

The abundance of Corophium volutator in Westerschelde marshes averaged around 6000 ind. $\mathrm{m}^{-2}$ (Hampel 2003). Cattrijsse (1994) even reported maximum autumn densities of 40000 ind. $\mathrm{m}^{-2}$ from 2 mesohaline marsh creeks. On the intertidal flats, Ysebaert et al. (1993) observed densities of C. volutator between 3000 and 10000 ind. $\mathrm{m}^{-2}$. The density of oligochaetes varied with salinity. At the oligohaline marsh stations, the density of oligochaetes was much lower (Hampel 2003) than on the intertidal flat (Ysebaert \& Herman 2002), while, in euhaline marsh creeks (Hampel 2003), densities were comparable with those on the estuarine flat (Ysebaert \& Herman 2002). Salgado et al. (2004a) mention their unpublished data, which shows lower infauna density in marsh creeks in comparison with on adjacent mudflats. Hampel (2003) examined the relationship between the densities and biomass of the main benthic prey (C. volutator and Nereis diversicolor) and the number of flounder and sea bass migrating into the creek, but no correlation was found between these factors. The lack of such a relationship may be a reflection of the excess carrying capacity, as shown by the large excess of macrobenthic prey, although the relatively few sampling occasions might have weakened the statistical test.

Apart from the infauna, other marsh invertebrates may serve as profitable prey for marsh-foraging fish or crustaceans. The semi-terrestrial amphipod Orchestia gammarellus often features as a prominent prey for sea bass (Laffaille et al. 2000b, Hampel et al. 2005) and for gobies leaving European marsh creeks with ebb tide (Laffaille et al. 1999, 2001b). This species often reaches huge abundances on the marsh surface amongst decaying plant material (Desender \& Maelfait 1999) and gets washed into the water during the highest tides. O. gammarellus does not occur in the intertidal and, due to its size and limited swimming abilities, is a favourable prey for foraging fish (Laffaille et al. 2000b).

Seasonal and even year-to-year fluctuations in infaunal abundances may differ between marsh creeks and adjacent habitats, like intertidal flats. We still lack a study describing seasonal changes in prey faunal abundance between marshes and adjacent environments and its possible effects on the use of marsh creeks as foraging grounds.

Not all fish present in the marsh-bordering subtidal enter intertidal marsh creeks to feed upon the marsh infauna. Mechanisms other than better foraging opportunities may force some species to enter intertidal creeks. It has often been argued that entering the intertidal habitat is a trade off between the risks of exposure to an extreme environment and/or the risk of stranding in intertidal pools and the benefits of high food availability and lack of predators. Competition might force some species into the intertidal and actually place them in a less favourable position than the species remaining in the subtidal. This is the case for the common goby. Sympatric occurrence with the sand goby forces this smaller species to occupy shallower areas (Magnhagen \& Wiederholm 1982). If the marsh environment is such a beneficial place to reside in, then why do not all species take advantage of the tides to enter? Studies comparing fish species counts between marsh and adjacent intertidal or subtidal areas often show that the subtidal is richer in species (Salgado et al. 2004a).

\section{Is predation pressure reduced in salt marsh habitats?}

Both growth rate and predation risk influenced habitat use by Fundulus heteroclitus in intertidal salt marshes (Halpin 2000). Vegetation provides efficient cover against predation. Experiments with tethered prey proved the lowered predation in marsh habitats compared with nonvegetated sand bottoms (Minello 1993). Using mummichogs in vegetated and unvegetated areas also revealed that relative predation pressure was significantly less in areas with submerged aquatic vegetation (Rozas \& Odum 1988). Survival of penaeid shrimp in subtidal biotopes is correlated with 
their residence time in marshes (Minello et al. 1989). Webb \& Kneib (2004) also found a strong correlation between mean growth rates of white shrimp Litopenaeus setiferus and the proportion of intertidal creek drainage area. Trade offs between predation refuge and growth define the use of different marsh habitats by fish. Where predation risk is high across all habitat types in a marsh, habitats associated with the highest growth rates are used. If a predation refuge is available, habitat use increases. Salt marshes offer opportunities for both higher growth rates and shelter from predation compared to areas outside salt marshes (Halpin 2000).

In the European marshes apart from the most upstream and smallest intertidal rivulets, where terrestrial plants may offer refuge and feeding habitat, the bare, unvegetated creek habitat is physically not very different than the unvegetated flat that exists in front of the marshes. The unvegetated creek habitat does not offer a higher habitat complexity that reduces predation pressure. At higher water levels, larger predatory fish also enter creeks to feed upon the smaller species (Hampel et al. 2005).

European literature only reports circumstantial evidence. Analysing the guild structure of European tidal marshes, Mathieson et al. (2000) found that the piscivore feeding guild was underrepresented in all studied estuarine sites, in sharp contrast with the fish assemblages of the main estuarine systems. The functional structure of marsh fish assemblages indicates the dominant presence of young stages and supports the view that predation pressure inside marsh creeks is lowered for those life stages.

Cattrijsse et al. (1997) argued in favour of lower predation in intertidal creeks for juvenile brown shrimp. They found early juvenile shrimp seldom occurring in the stomachs of small-sized fish feeding in the marsh, while in the subtidal many more predator species were present. Stomach analyses of large sea bass and flounder leaving marsh creeks have shown that the smallsized fish and juvenile Crangon crangon are not extensively consumed, while marsh infauna and mysids still dominate the diet (Hampel et al. 2005). Secondly, juvenile shrimp and common gobies remaining in intertidal pools in the creek bed find a temporary segregation from predation by other fish (Cattrijsse et al. 1994, 1997). Densities of juvenile brown shrimp may reach $>400$ ind. $\mathrm{m}^{-2}$ in the seepage water or in small pools of only a few centimetres depth (Cattrijsse et al. 1997). Hampel et al. (2004) also showed the high number of juvenile brown shrimp and gobies in marsh pools. Larger predators like sea bass and flounder did not venture into this habitat. The functioning and importance of European marsh pools as habitats for marsh nekton remain completely unknown. How do they function as temporary refuges? Is survival better or growth faster there? What influence does their position on the marsh, their dimension, or any other factor have on habitat value?

\section{Do marsh-visiting species exert a control on the marsh infauna?}

Intensive tidal foraging by tidal marsh-visiting nekton can result in important effects on the dynamics of individual prey populations (Joyce \& Weisberg 1986) and benthic (Frid \& James 1988) or epibenthic (Walters et al. 1996) communities. Effects may be due to disturbance or predation (Kneib 1997b). The very high productivity of Fundulus heteroclitus depends, to a considerable extent, on salt marsh food resources (Weisberg \& Lotrich 1982), and, thus, it seems reasonable to expect that mummichogs affect salt marsh invertebrate prey populations. F. heteroclitus was indeed reported to control the densities of Palaemonetes pugio (Kneib 1986). Predation by mummichogs was also a dominant factor determining the distribution and abundance of Orchestia grillus (Vince et al. 1976). In contrast with these observations, Kneib (1982) argued that the distribution of O. grillus was independent of the predation of $F$. heteroclitus, while Kneib \& Stiven (1982) also claimed that F. heteroclitus is an inefficient predator of small benthic invertebrates (small annelids and crustaceans) and does not directly control prey densities. Control mechanisms occurred indirectly through the predation upon grass shrimp. The absence of direct effects on marsh benthic invertebrates results from limited marsh accessibility, the necessity of daylight for predation and good refuge in the vegetation for the prey species (Heck \& Thoman 1981).

The effects of some macrocrustacean species were also examined. Grass shrimp Penaeus pugio were associated with reductions in the densities of small benthic invertebrates in salt marshes (Bell \& Coull 1978), while Penaeus spp. had a negative effect on prey species in both laboratory (Kneib \& Knowlton 1995) and field (Gleason \& Wellington 1988) experiments. Interaction of Callinectes sapidus and their molluscan prey in tidal marshes has also received considerable attention (Kneib 1997b).

In Europe, the only indication that marsh-visiting species may intensively prey upon and thus control their food resources within marshes was given by Frid \& James (1988), who observed a reduction in infaunal predators, but not in deposit feeders after exclusion of epibenthic predators (birds, crustaceans and fish). Hampel et al. (2005) found that marsh infauna was highly abundant for larger fish and control on benthic prey could not be assumed. 
If nursery species control their prey abundance, competition for food will occur. This limits the growth potential of the individuals, the production potential of the population and, consequently, the quantitative value of the nursery. Likely, year-to-year fluctuations in abundance of both predators and prey exclude yearto-year identical relationships between them.

\section{What biomass is exported when recruiting to the subtidal population?}

Tidal water movements control fluxes of nutrients and organic matter between salt marshes and estuarine/coastal water. Rozas et al. (1988) emphasised the importance of marsh creeks as important corridors through which nekton move marsh production between the vegetated intertidal and open subtidal in US marshes. Faunal species can be responsible for organic matter transport in river systems (Elliott et al. 1990, Maes \& Ollevier 2000) and in salt marshes (Lefeuvre et al. 1999). Beck et al. (2001) advocate that total biomass of juveniles recruiting to the adult population is the best criterion in determining the value of a nursery.

Productivity estimates for salt marsh population of Fundulus heteroclitus are among the highest reported for fish (Meredith \& Lotrich 1979). Allen (1982) estimated that the total annual production in dry weight (DW) of assemblages of fishes in the littoral zone of a tidal marsh in California was $9.5 \mathrm{~g} \mathrm{DW} \mathrm{m}^{-2}$. Forman (1982) and Laffaille et al. (1998) showed that fish invade salt marshes during flood tide, forage there and export the ingested food to the coastal waters upon leaving the marsh. Mullets directly use the primary production of salt marshes and are thus involved in energy fluxes between salt marshes and coastal marine systems (Laffaille et al. 2002). According to Lefeuvre et al. (1999) mullets would export about 8 to $12 \mathrm{~kg}$ organic matter ha ${ }^{-1}$. Laffaille et al. (1998) estimated that fish (mullets, gobies, sea bass) export $0.01 \mathrm{t}$ particulate organic matter $\mathrm{yr}^{-1}$ from each hectare of salt marsh in the Mont Saint-Michel Bay to the marine system. The energy transported by fish may account for as much as $10 \%$.

Not only fish, but also the macrocrustacean-like Crangon crangon, could be responsible for the export of biomass from tidal marsh creeks. Young-of-the-year C. crangon spend approximately $3 \mathrm{wk}$ in the tidal creeks of the oligohaline part of the Westerschelde. One year of constant outflux of young C. crangon between April and October from a $27 \mathrm{~km}^{2}$ marsh had the potential of exporting the production of the Belgian coastal shrimp fisheries of that year (Cattrijsse et al. 1997).

\section{Are European marsh creeks still important nurseries?}

Watzin \& Gosselink (1992) have estimated that $>50 \%$ of the original tidal salt marsh habitats in the United States have been eliminated by various human activities. Despite this loss, fishery species are believed to depend upon the access of intertidal wetlands.

US fishery productivity is closely linked to wetlands, and both correlative (Zimmerman \& Minello 1984, Rozas \& Reed 1993, Peterson \& Turner 1994) and experimental (Minello \& Zimmerman 1983, 1991, Minello et al. 1989, Thomas 1989) evidence indicates that many fisheries species in the region of the northern Gulf of Mexico depend upon coastal marshes for critical nursery functions. The best-known examples are the blue crab and the penaeid shrimp. Some papers have argued and shown figures that their commercial catches depend upon the available amount of marsh land (Orth \& van Montfrans 1990). Turner $(1977,1992)$ provided evidence for the importance of coastal marshes to prawn production, by relating inshore catches of penaeids to regional variation in the areal extent of intertidal vegetation. Webb \& Kneib (2002) found a correlation between the amount of intertidal creek edge and juvenile shrimp abundance in adjacent subtidal creeks, which supports the contention that intertidal accessibility is an important component of nursery habitat quality for juvenile white shrimp.

On the European continent the claiming of intertidal areas is a centuries-old practice that is currently still threatening the remainder of the formerly extensive intertidal, vegetated ecosystems. This process removed $>7200 \mathrm{~km}^{2}$ of estuarine habitats during the 20th century alone (Davidson et al. 1991, Cattrijsse et al. 2002).

Only a limited number of species using European tidal marshes as nurseries are fishery species. Although, Costa et al. (1994) claimed that the salt marsh-bordering zone in the Mira estuary (Portugal) has a vital importance for both estuarine and marine fish populations as spawning and nursery grounds, especially for economic species. In northern Europe, the list is confined to brown shrimp and sea bass, the latter not being amongst the most abundant species. In southern Europe, sea bass Dicentrarchus labrax, pilchard Sardina pilchardus and thin-lipped mullet Liza ramada are the main commercial species (Salgado et al. 2004b). Pilchard does not occur abundantly in northern Europe, while the mullet is not a commercial species there. Salt marshes are thought to play a key role in the production of the sea bass commercial fishery in the region of Mont-Saint Michel Bay (Lefeuvre et al. 2000). Kennedy \& Fitzmaurice (1972) and Kelley 
(1986, 1988) have previously mentioned the importance of shallow creeks for sea bass.

The absence of historical data excludes any assessment on the impact of the gradual, but significant, disappearance of European marsh areas on commercial catches. These species do not seem to depend solely on marshes for the survival of their offspring anyway. Crangon crangon spend their earliest days in marsh creeks (Cattrijsse et al. 1997), but their most important nurseries are the shallow sandy beaches of the North Sea coast (Boddeke et al. 1986). Also, sea bass regularly use marsh creeks (Kennedy \& Fitzmaurice 1972, Kelley 1988, Cattrijsse et al. 1994, Laffaille et al. 2001a, Salgado et al. 2004b), but they occur abundantly along intertidal estuarine sand and mudflats (Kennedy \& Fitzmaurice 1972, Hostens 2000). Alternativebetter? - nurseries have always been and still are present for these species, and the hypothesis that marshes support past or present fishery yields in Europe can be questioned, at least for these examples.

Do marsh creeks reach the same quantitative importance every growth season and how does this relate to the abundance of prey populations inside and outside marsh habitats? To date, no long-term data on abundance or feeding intensity of marsh-visiting species are available. Monitoring of marsh habitats would help in a better long-term appreciation of the habitat role of intertidal marshes for fish or macrocrustaceans.

\section{Would local fish populations suffer from further/ complete disappearance of tidal marshes?}

European marshes have probably shrunk to an areal coverage too limited to be of importance for regional or even local populations of fish or crustaceans. Weisberg \& Lotrich $(1982,1986)$ showed that Fundulus heteroclitus is fully dependant upon the existence of vegetated intertidal areas. Individuals restrained from access to the marsh surface grew more slowly, and individuals staying in the subtidal were subject to higher predation. Moreover, subtidal food sources alone were insufficient to support growth of $F$. heteroclitus. Access to the food resources of the vegetated marsh surface was essential to maintain the natural mummichog population. F. heteroclitus restricted to foraging in subtidal channels lost weight, while those accessing the marsh surface grew at an average rate of $0.34 \%$ of their body weight (BW) per day.

In European marshes Pomatoschistus microps or $P$. minutus may occupy a similar niche in intertidal marshes (Cattrijsse et al. 1994). The first species may reach a daily consumption of up to $10 \%$ ADW (ash-free dry weight) (Hampel et al. 2003a), but this does not prove a dependence on the marsh for feeding. Con- sumption or growth should differ between individuals with and individuals without access to the marsh intertidal. The influence of biological relationships may play a role in this (Magnhagen \& Wiederholm 1982).

Apart from feeding, marshes can be essential for the spawning or development of several species. Fundulus heteroclitus spawns in the intertidal, depositing large eggs in shelters like mussel shells, leaves and grass stems (Taylor et al. 1977). The hatched young spend several weeks in aquatic microhabitats on the marsh surface (Taylor et al. 1979). The recruitment of the mummichog is closely related to marsh habitats, which makes them dependent on intertidal marshes during their life cycle. Menidia menidia exhibits a similar spawning behaviour (Conover \& Kynard 1984). Sticklebacks (Kedney et al. 1987) and the goby Gobiosoma bosc (Conn \& Bechler 1996) also prefer intertidal marsh pools, but these species also spawn in subtidal habitats. Post-larval palaemonid shrimps are uncommon in subtidal creeks (Alon \& Stancyk 1982), because metamorphosis probably occurs in the intertidal marsh, where post-larvae settle primarily (Kneib 1987).

None of the European marsh-visiting species depends on marshes as spawning habitats. The most common marsh species (gobies, flounder, sea bass, sole) spawn in coastal waters and not inside the marsh biotope. Other shallow estuarine or coastal environments play a significant nursery role for these species.

Tidal consumption of marsh-foraging fish can reach high figures. Hampel \& Cattijsse (2004) have estimated that, according to the lunar cycle, the daily consumption ( 2 tides) of common gobies varies between 7 and $16 \%$ of their body dry weight. Similar estimates were obtained for thin-lipped mullet ( $8 \%$ BW) by Laffaille et al. (2002) and for sand gobies (4.5\% BW) and seabass (10\% BW) by Lefeuvre et al. (1999).

To date, no observations exist that any of these species depends fully on the intertidal marshes as a refuge or foraging ground. It remains unknown whether any of the European marsh species exhibits faster growth rates or benefits from enhanced survival during their marsh residence. Laffaille et al. (1999, 2001a) have reported on the likelihood of 'easy' foraging, but acknowledge that future research should address the link between salt marshes and the sustainability of fish populations. Future European research could focus on growth rates of marsh-foraging species in comparison with conspecifics that have no access to marsh creeks.

\section{RESTORATION AND RE-CREATION OF INTERTIDAL MARSH HABITATS}

In the United States each square metre of marsh lost must be mitigated, and considerable effort has been 
made in the last couple of decades to restore or create intertidal areas. In the European Union, the Habitats Directive regulates the conservation of Sites of Community Importance (SCIs) and seeks to maintain habitat levels on a no-net-loss basis within large, designated areas (Crooks et al. 2001). There is a marked difference between the European approach of managed retreat and the restoration programmes in the United States. In Europe coastal defence is the primary objective, while in the United States restoration is the primary policy (Pethick 2002). In the United States, there are few complications concerning space, whereas, in Europe, each restored hectare generates heated debates due to the interests of different sectors. While in the United States marsh is created/re-created, in Europe, managed retreat/realignment is the most widely used management tool to mitigate wetland loss. Managed retreat and set back involve allowing the degradation of current sea defences or dikes and moving them further inland. Areas of land given back to the estuary and evolving into salt marshes will pay for themselves in the reduced cost of later flood- and seadefence schemes. The reactivated coastal and estuarine floodplains provide both habitat and a self-sustaining flood defence (Lee 2001). The fast erosion of the east coast of the UK intertidal made realignment of flood defences an important issue and a main coastal management strategy (Crooks et al. 2002). In Belgium 'controlled inundation areas', where dikes are opened on a regular basis, have the potential of developing into similar systems and could, in the future, become true tidal ecosystems. Choices to relocate habitat and restore intertidal marshes must be made with care (Crooks et al. 2002). Scientific research in the UK has focused on modelling estuarine morphology and, more recently, on unmanaged retreat (breached flood embankments not being repaired) (Pethick 2002). Some experimental restorations have been undertaken in the UK, but they are $<6$ yr old, so long-term conclusions cannot be drawn yet (Atkinson et al. 2001). Studies concerning wetland restoration are still scarce for Europe compared to those for the United States. A large number of studies have been published in the United States about monitoring the colonisation of plant species, benthic invertebrates and nekton after marsh creation. Most of these assume that many newly created salt marshes offer similar fish species composition and densities as natural marsh habitats in a relatively short period of time (Minello \& Webb 1997, Dionne et al. 1999, Williams \& Zedler 1999, Williams \& Desmond 2001). In Europe, only very few studies have monitored nekton utilisation in re-created areas. In the Westerschelde estuary, a newly created estuarine marsh developed some functions of a typical marsh (e.g. refuge) for estuarine nekton relatively quickly, but full functional development may require $>10 \mathrm{yr}$ (Hampel et al. 2003b). In the Humber estuary, UK, research is being done on the colonisation of newly created areas, but conclusions cannot be drawn yet. Creating new marshes in West Europe would allow nekton species to rapidly colonise the system, regardless of the lower potential as a feeding ground and thus as a nursery area. Probably, the creation of new marshes will only be as beneficial as mature marsh systems to fish and crustacean populations, medium to long term.

Along the freshwater reaches of the Schelde estuary 'Controlled Inundation Areas' are being constructed as a major, natural management scheme against flooding of the former river floodplains. These low-lying pastures only flood during the highest tides, but fish will and do invade these new habitats, which eventually could develop into tidal freshwater marshes. The lack of knowledge on the habitat value of freshwater marshes to fish (Hampel et al. 2004) makes it difficult to evaluate the ecological consequences of such river management. Freshwater marshes are often dominated by reed Phragmites australis, and it has been shown for North American marshes in which this plant species is an intrusive alien that reed habitat and Spartina marshes function similarly (Meyer et al. 2001).

Northern European tidal marshes have been used as foraging grounds for cattle and sheep since the earliest human coastal settlements. Nowadays grazing is generally used to increase habitat complexity and overall marsh flora and fauna species diversity. The effect of grazing management presents an issue that is unique to northern European tidal marshes, and only Laffaille et al. (2000b) have addressed it. They showed that intensive grazing reduces litter and habitat suitability on the marsh surface for the semi-terrestrial amphipod Orchestia gammarellus. As a consequence, the abundance of this amphipod is reduced. Laffaille et al. (2001a) proved that this amphipod is a high-energy food item that young sea bass actively forage on during residence in intertidal marsh creeks. Other management issues that aim at preserving the biodiversity of coastal or estuarine tidal marshes might equally have negative effects on the aquatic fauna, which are still not known well enough to sustain tidal marsh management.

Current estuarine management of both mature and new marshes will present promising opportunities for future European research. Follow up studies of the colonisation effects of realigned marshes by nekton as well as long-term monitoring of nekton will sustain future management schemes and are needed to evaluate ongoing or future human activities in the coastal or estuarine environment. 


\section{LITERATURE CITED}

Adam P (1990) Saltmarsh ecology. Cambridge University Press

Allen EA, Fell PE, Peck MA, Gieg JA, Guthke CR, Newkirk M (1994) Gut contents of common mummichogs, Fundulus heteroclitus (L.), in a restored impounded marsh and in natural reference marshes. Estuaries 172:462-471

Allen LG (1982) Seasonal abundance, composition and productivity of the littoral fish assemblage in upper Newport Bay, California. Fish Bull 80:769-790

Alon NC, Stancyk SE (1982) Variation in life-history patterns of the grass shrimp Palaemonetes pugio in two South Carolina estuarine systems. Mar Biol 68:265-276

Atkinson PW, Crooks S, Grant A, Rehfisch MM (2001) The success of creation and restoration schemes in producing intertidal habitat suitable for waterbirds. English Nature Research Report 425, English Nature, Petersborough

Beck MW, Heck KL, Able KW, Childers DL and 9 others (2001) The identification, conservation, and management of estuarine and marine nurseries for fish and invertebrates. Bioscience 51(8):633-641

Beeftink WG (1977) The coastal salt marshes of western and northern Europe: an ecological and phytosociological approach. In: Chapman V (eds) Wetland coastal ecosystems. Elsevier, Amsterdam, p 109-155

Beeftink WG, Rozema J (1988) The nature and functioning of salt marshes. In: Salomons W, Bayne BL, Duwsma EK, Förstner V (eds) Pollution of the North Sea: an assessment. Springer, Berlin, p 59-87

Bell SS, Coull BC (1978) Field evidence that shrimp predation regulates meiofauna. Oecologia 35:141-148

Boddeke R, Driessen G, Doesburg W, Ramaekers G (1986) Food availability and predation presence in a coastal nursery area of the brown shrimp (Crangon crangon). Ophelia 26:77-90

Boesch DF, Turner RE (1984) Dependence of fishery species on salt marshes: the role of food and refuge. Estuaries 7 : $460-468$

Bouchard V, Lefeuvre JC (2000) Primary production and macro-detritus dynamics in a European salt marsh: carbon and nitrogen budgets. Aquat Bot 67:23-42

Burrows MT, Gibson RN, Maclean A (1994) Effects of endogenous rhythms and light conditions on foraging and predator-avoidance in juvenile plaice. J Fish Biol 45:171-180

Cabral HN (2000) Comparative feeding ecology of sympatric Solea solea and $S$. senegalensis, within the nursery areas of the Tagus estuary, Portugal. J Fish Biol 57:1550-1562

Cabral H, Costa MJ (2001) Abundance, feeding ecology and growth of 0-group sea bass, Dicentrarchus labrax, within the nursery areas of the Tagus estuary. J Mar Biol Assoc UK 81:679-682

Cain RL, Dean JM (1976) Annual occurrence, abundance and diversity of fish in a South Carolina intertidal creek. Mar Biol 36:369-379

Cattrijsse A (1994) Schorkreken in het brakke deel van het Westerschelde estuarium als habitat voor vissen en macrocrustacea. PhD dissertation, University of Gent

Cattrijsse A, Makwaia ES, Dankwa HR, Hamerlynck O, Hemminga MA (1994) Nekton communities of an intertidal creek of a European estuarine brackish marsh. Mar Ecol Prog Ser 109:195-208

Cattrijsse A, Dankwa HR, Mees J (1997) Nursery function of an estuarine tidal marsh for the brown shrimp Crangon crangon. J Sea Res 38:109-121

Cattrijsse A, Codling I, Conides A, Duhamel S, Gibson RN, Hostens K, Mathieson S, McLusky DS (2002) Estuarine development/habitat restoration and re-creation and their role in estuarine management for the benefit of aquatic resources. In: Elliot M, Hemingway K (eds) Fishes in estuaries. Blackwell Sciences, Oxford, p 266-321

Conn CH, Bechler DL (1996) Reproductive strategies in a population of Gobiosome bosci (Osteichthyes: Gobiidae) with slow and fast maturing individuals. Gulf Res Rep 9: 177-182

Connolly RM (1999) Saltmarsh as habitat for fish and nektonic crustaceans: challenges in sampling designs and methods. Aust J Ecol 24:422-430

Conover DO, Kynard BE (1984) Field and laboratory observations of spawning periodicity and behavior of northern population of Atlantic silverside, Menidia (Pisces: Atherinidae). Environ Biol Fish 11:161-171

Costa MJ, Almeida PR, Costa JL, Assis CA (1994) Do eel grass beds and salt marsh borders act as preferential nurseries and spawning grounds for fish? An example of the Mira estuary in Portugal. Ecol Eng 3:187-195

Costa M, Catarino F, Bettencourt A (2001) The role of salt marshes in the Mira estuary (Portugal). Wetlands Ecol Manage 9:121-134

Craig JK, Crowder LB (2000) Factors influencing habitat selection in fishes with a review of marsh ecosystem. In: Weinstein MP, Kreeger DA (eds) Concepts and controversies in tidal marsh ecology. Kluwer Academic Publisher, Dordrecht, p 241-267

Crooks S, Ledoux L, Fairbrass J (2001) No-net-loss the European Union way. Natl Wetlands Newsl 23:15-17

Crooks S, Schutten J, Sheern DG, Pye K, Davy JA (2002) Drainage and elevation as factors in the restoration of salt marsh in Britain. Restor Ecol 10:591-602

Dame RF, Gardner LR (1993) Nutrient processing and the development of tidal creek ecosystems. Mar Chem 43: 175-183

Dame RF, Lefeuvre JC (1994) Tidal exchange: import-export of nutrients and organic matter in new and old world salt marshes: conclusions. In: Mitsch WJ (eds) Global wetlands: Old and New World. Elsevier Science, Amsterdam, p 303-305

Davidson NC, Laffoley D, Doody JP, Way JS and 5 others (1991) Nature conservation and estuaries in Great Britain. Joint Nature Conservation Committee, Petersborough

Davis TLO (1988) Temporal changes in the fish fauna entering a tidal swamp system in tropical Australia. Environ Biol Fish 21:161-172

Day JW Jr, Pont D, Hensel PF, Ibanez C (1995) Impacts of sealevel rise on deltas in the Gulf of Mexico and the Mediterranean: the importance of pulsing events to sustainability. Estuaries 18:636-647

Desender K, Maelfait JP (1999) Diversity and conservation of terrestrial arthropods in tidal marshes along the River Schelde: a gradient analysis. Biol Conserv 87:221-229

Dionne M, Short FT, Burdick DM (1999) Fish utilization of restored, created, and reference salt-marsh habitat in the Gulf of Maine. Am Fish Soc Symp 22:384-404

Drake P, Arias AM (1991a) Composition and seasonal fluctuations of the ichthyoplankton community in a shallow tidal channel of Cadiz Bay (S.W. Spain). J Fish Biol 39:245-263

Drake P, Arias AM (1991b) Ichthyoplankton of a shallow coastal inlet in south-west Spain: factors contributing to colonization and retention. Estuar Coast Shelf Sci 32: 347-364

Elliott M, O'Reilly MG, Taylor CJL (1990) The Forth Estuary: a nursery and overwintering area for North Sea fishes. Hydrobiologia 195:89-103

Elliott M, Hemingway KL, Costello MJ, Duhamel S, Hostens 
K, Laropoulou M, Marshall S, Winkler H (2002) Links between fish and other trophic levels. In: Elliott M, Hemingway $\mathrm{K}$ (eds) Fishes in estuaries. Blackwell Science, Oxford, p 124-217

Forman RTT (1982) Interaction among landscape elements: a core of landscape ecology. In: Tjallingii SP, de Veer AA (eds) Perspectives in landscape ecology. Proc Int Congr Neth Soc Landscape Ecol. Centrum voor Landbouwpublikaties en landbouwdocumentatie, Wageningen, p 35-48

Frid CLJ (1988) The marine fauna of the north Norfolk salt marshes and their ecology. Trans Norfolk Norwich Nat Soc 28:46-50

Frid CLJ, James R (1989) The marine fauna of a British coastal salt marsh. Holarct Ecol 12:9-15

Gardner J (1996) The use of saltmarshes and adjacent intertidal mudflats as fish feeding areas. MSc dissertation, University of Hull

Gibson RN (1973) Tidal and circadian activity rhythms in juvenile plaice, Pleuronectes platessa. Mar Biol 22:379-386

Gibson RN (1993) Intertidal teleosts: life in a fluctuating environment. In: Pitcher TJ (eds) Behaviour of teleost fishes. Chapman \& Hall, London, p 513-536

Gleason DF, Wellington GM (1988) Food resources of postlarval brown shrimp (Penaeus aztecus) in a Texas coastal salt marsh. Mar Biol 97:329-337

Halpin PM (2000) Habitat use by an intertidal salt-marsh fish: trade-offs between predation and growth. Mar Ecol Prog Ser 198:203-214

Hampel H (2003) Factors influencing the habitat value of tidal marshes for nekton in the Westerschelde estuary. $\mathrm{PhD}$ dissertation, University of Gent

Hampel H, Cattrijsse A (2004) Diel, tidal and lunar feeding rhythms in a tidal marsh population of Pomatoschistus microps. Aquat Sci 66:315-326

Hampel H, Cattrijsse A, Vincx M (2003a) Effect of tidal, diel and lunar cycle to the nekton communities in a salt marsh of the Westerschelde. Estuar Coast Shelf Sci 56:795-805

Hampel H, Cattrijsse A, Vincx M (2003b) Habitat value of a developing marsh for fish and macrocrustaceans. ICES J Mar Sci 60:278-289

Hampel H, Cattrijsse A, Mees J (2004) Changes in marsh nekton communities along the salinity gradient of the Schelde estuary, Belgium. Hydrobiologia 515:137-146

Hampel H, Cattrijsse A, Elliott M (2005) Feeding habit of young predator fishes in marsh creeks situated along the salinity gradient of the Westerschelde estuary, The Netherlands. Helgol Mar Res 59:151-162

Heck KL Jr, Thoman TA (1981) Experiments on predatorprey interactions in vegetated aquatic habitats. J Exp Mar Biol Ecol 53:125-134

Hemminga MA, Klap VA, van Soelen J, de Leeuw J (1992) Shifts in seston characteristics after inundation of a European coastal salt marsh. Limnol Oceanogr 37:1559-1564

Hemminga MA, Klap VA, van Soelen J, Boon JJ (1993) Effect of salt marsh inundation on estuarine particulate organic matter characteristics. Mar Ecol Prog Ser 99:153-161

Hostens K (2000) Spatial patterns and seasonality in the epibenthic communities of the Westerschelde (southern bight of the North Sea). J Mar Biol Assoc UK 80:27-36

Hostens K (2003) The demersal fish and macro-invertebrate assemblages of the Westerschelde and Oosterschelde estuaries (southern bight of the North Sea). PhD dissertation, University of Gent

Irlandi EA, Crawford MK (1997) Habitat linkages: the effect of intertidal saltmarshes and adjacent habitats on abundance, movement, and growth of an estuarine fish. Oecologia 110:222-230
Joyce AA, Weisberg SB (1986) The effects of predation by the mummichog, Fundulus heteroclitus (L), on the abundance and distribution of the salt-marsh snail, Melampus bidentatus (Say). J Exp Mar Biol Ecol 100:295-306

Kedney GI, Boule V, Fitzgerald GJ (1987) The reproductive ecology of three spined sticklebacks breeding in fresh and brackish water. Am Fish Soc Symp 1:151-161

Kelley D (1986) Bass nurseries on the west coast of the UK. J Mar Biol Assoc UK 66:439-464

Kelley DF (1988) The importance of estuaries for seabass, Dicentrarchus labrax (L.). J Fish Biol 33:25-33

Kelley DF, Reay PJ (1988) The shallow creek fish communities of Southwest England and West Wales estuaries. J Fish Biol 33:221-222

Kennedy M, Fitzmaurice P (1972) Biology of bass, Dicentrarchus labrax, in Irish waters. J Mar Biol Assoc UK 52:557

Kennish MJ (2001) Coastal salt marsh systems in the US: a review of anthropogenic impacts. J Coast Res 17:731-748

Kerr RA (1989) Bringing down the sea level rise. Science 246: 563

Kneib RT (1982) Habitat preference, predation and the intertidal distribution of gammaridean amphipods in a North Carolina salt marsh. J Exp Mar Biol Ecol 59:219-230

Kneib RT (1986) The role of Fundulus heteroclitus in salt march trophic dynamics. Am Zool 26:259-269

Kneib RT (1987) Seasonal abundance, distribution and growth of postlarval and juvenile grass shrimp (Palaemonetes pugio) in a Georgia, USA, salt marsh. Mar Biol 96: 215-223

Kneib RT (1997a) Early life stages of resident nekton in intertidal marshes. Estuaries 20:214-230

Kneib RT (1997b) The role of tidal marshes in the ecology of estuarine nekton. Oceanogr Mar Biol Annu Rev 35: 163-220

Kneib RT, Knowlton MK (1995) Stage-structured interactions between seasonal and permanent residents of an estuarine nekton community. Oecologia 103:425-434

Kneib RT, Stiven AE (1982) Benthic invertebrate responses to size and density manipulations of the common mummichog, Fundulus heteroclitus, in an intertidal salt marsh. Ecology 63:1518-1532

Kneib RT, Wagner SL (1994) Nekton use of vegetated marsh habitats at different stages of tidal inundation. Mar Ecol Prog Ser 106:227-238

Labourg PJ, Clus C, Lasserre G (1985) Résultats preliminaries sur la distribution des juveniles de poisons dans un marais maritime du Bassin d'Arcachon. Oceanol Acta 8:331-341

Laffaille P, Brosse S, Feunteun E, Baisez A, Lefeuvre JC (1998) Role of fish communities in particulate organic matter fluxes between salt marshes and coastal marine waters in the Mont Saint-Michel Bay. Hydrobiologia 373/374: 121-133

Laffaille P, Feunteun E, Lefeuvre JC (1999) Compétition alimentaire entre deux espéces de gobies, Pomatoschistus lozanoi (de Buen) et P. minutus (Pallas), dans un marais salé macrotidal. Ecologie 322:897-906

Laffaille P, Feunteun E, Lefeuvre JC (2000a) Composition of fish communities in a European macrotidal salt marsh (the Mont Saint-Michel Bay, France). Estuar Coast Shelf Sci 51: 429-438

Laffaille P, Feunteun E, Lefeuvre JC (2000b) Impact of sheep grazing on juvenile sea bass, Dicentrarchus labrax L., in tidal salt marshes. Biol Conserv 96:271-277

Laffaille P, Lefeuvre JC, Schricke MT, Feunteun E (2001a) Feeding ecology of 0-group sea bass, Dicentrarchus labrax, in salt marshes of Mont Saint Michel Bay (France). Estuaries 24:116-125 
Laffaille P, Thieulle L, Feunteun E, Lefeuvre JC (2001b) Composition of fish community in small anthropic estuary (the 'Couesnon', France). Bull Fr Peche Piscic 357-360: 191-208

Laffaille P, Feunteun E, Lefebvre C, Radureau A, Sagan G, Lefeuvre JC (2002) Can thin-lipped mullet directly exploit the primary and detric production of European macrotidal salt marshes? Estuar Coast Shelf Sci 54:729-736

Lee M (2001) Coastal defense and the habitat directive: predictions of habitat change in England and Wales. Geogr J 167:39-56

Lefeuvre JC, Dame RF (1994) Comparative studies of salt marsh processes in the New and Old Worlds: an introduction. In: Mitsch WJ (eds) Global wetlands: Old and New World. Elsevier Science, Amsterdam, p 169-179

Lefeuvre JC, Bertru G, Burel F, Brient L and 8 others (1994) Comparative studies on salt marsh processes in the Baie du Mont Saint-Michel: a multi-disciplinary study. In: Mitsch WJ (eds) Global wetlands: Old and New World. Elsevier, Amsterdam, p 215-234

Lefeuvre JC, Laffaille P, Feunteun E (1999) Do fish communities function as biotic vectors of organic matter between salt marshes and marine coastal waters? Aquat Ecol 33: 293-299

Lefeuvre JC, Bouchard V, Feunteun E, Grare S, Laffaille P, Radureau A (2000) European salt marsh diversity and functioning: the case study of the Mont Saint-Michel Bay, France. Wetlands Ecol Manage 8:147-161

Maes J, Ollevier F (2000) Biomass transport to and from an upper estuarine area by migration of juvenile Atlantic herring, Clupea harengus. Can J Fish Aquat Sci 57: 1404-1409

Maes J, Taillieu A, Van Damme P, Ollevier F (1997) The composition of the fish and crustacean community of the Zeeschelde Estuary (Belgium). Belg J Zool 127:47-55

Magnhagen C, Wiederholm AM (1982) Food selectivity versus prey availability: a study using the marine fish Pomatoschistus microps. Oecologia 55:311-315

Mathieson S, Cattrijsse A, Costa MJ, Drake P, Elliott P, Gardner J, Marchand J (2000) Fish assemblages of European tidal marshes: a comparison based on species, families and functional guilds. Mar Ecol Prog Ser 204:225-242

Meredith WH, Lotrich VA (1979) Production dynamics of a tidal creek population of Fundulus heteroclitus (Linnaeus). Estuar Coast Mar Sci 8:99-118

Meyer DL, Johnson JM, Gill JW (2001) Comparison of nekton use of Phragmites australis and Spartina alterniflora marshes in the Chesapeake Bay, USA. Mar Ecol Prog Ser 209:71-84

Minello TJ (1993) Chronographic tethering - a technique for measuring prey survival-time and testing predation pressure in aquatic habitats. Mar Ecol Prog Ser 101:99-104

Minello TJ (1999) Nekton densities in shallow estuarine habitats of Texas and Louisiana and the identification of essential fish habitat. Am Fish Soc Symp 22:43-75

Minello TJ, Webb JW (1997) Use of natural and created Spartina alterniflora salt marshes by fishery species and other aquatic fauna in Galveston Bay, Texas, USA. Mar Ecol Prog Ser 151:165-179

Minello TJ, Zimmerman RJ (1983) Fish predation on juvenile brown shrimp, Penaeus aztecus Ives: the effect of simulated Spartina structure on predation rates. J Exp Mar Biol Ecol 72:211-231

Minello TJ, Zimmerman RJ (1991) The role of estuarine habitats in regulating growth and survival of juvenile penaeid shrimp. In: De Loach P, Dougherty WJ, Davidson MA (eds) Frontiers in shrimp research. Elsevier, Amsterdam, p 1-16
Minello TJ, Zimmerman RJ, Marinez EX (1989) Mortality of young brown shrimp Penaeus aztecus in estuarien nurseries. Trans Am Fish Soc 118:693-708

Mitsch WJ, Mitsch RH, Turner RE (1994) Wetlands of the Old and New Worlds: ecology and management. In: Mitsch WJ (eds) Global wetlands: Old and New World. Elsevier Science, Amsterdam, p 3-56

Morton RM, Pollock BR, Beumer JP (1987) The occurrence and diet of fishes in a tidal inlet to a saltmarsh in southern Moreton Bay, Queensland. Aust J Ecol 12:217-237

Netto SA, Lana PC (1997) Intertidal zonation of benthic macrofauna in a subtropical salt marsh and nearby unvegetated flat (SE, Brazil). Hydrobiologia 353:171-180

Nixon SW (1980) Between coastal marshes and coastal waters - a review of twenty years of speculation and research on the role of salt marshes in estuarine productivity and water chemistry. In: Hamilton P, Macdonald KB (eds) Estuarine and wetland processes with emphasis on modelling. Plenum Press, New York, p 437-525

Odum WE, Heald EJ (1975) The detritus-based foodweb of an estuarine mangrove community. In: Cronin LE (ed) Estuarine research, Vol 1. Academic Press, New York

Orth RJ, van Montfrans J (1990) Utilization of marsh and seagrass habitats by early life stages of Callinectes sapidus: a latitudinal perspective. Bull Mar Sci 46:126-144

Paterson AW, Whitfield AK (1996) The fishes associated with an intertidal salt marsh creek in the Kariega Estuary, South Africa. Trans R Soc S Afr 51:195-218

Paterson AW, Whitfield AK (2000) Do shallow-water habits function as refugia for juvenile fishes? Estuar Coast Shelf Sci 51:359-364

Peterson GW, Turner RE (1994) The value of salt marsh edge vs. interior as a habitat for fish and decapod crustaceans in a Louisiana tidal marsh. Estuaries 17:235-262

Pethick J (2002) Estuarine and tidal wetland restoration in the United Kingdom: policy versus practice. Restor Ecol 10: 431-437

Pihl L, Cattrijsse A, Codling I, Mathieson S, McLusky DS, Roberts C (2002) Habitat use by fishes in estuaries and other brackish areas. In: Elliott M, Hemingway K (eds) Fishes in estuaries. Blackwell Science, Oxford, p 10-54

Reimold RJ (1977) Mangals and salt marshes of eastern United States. In: Chapman VJ (eds) Wet coastal ecosystems. Elsevier, Amsterdam, p 157-166

Rozas LP (1995) Hydroperiod and its influence on nekton use of the salt marsh: a pulsing ecosystem. Estuaries 18: $579-590$

Rozas LP, Minello TJ (1997) Estimating densities of small fishes and decapod crustaceans in shallow estuarine habitats: a review of sampling design with focus on gear selection. Estuaries 20:99-213

Rozas LP, Minello TJ (1998) Nekton use of salt marsh, seagrass, and nonvegetated habitats in a south Texas (USA) estuary. Bull Mar Sci 63:481-501

Rozas LP, Odum WE (1988) Occupation of submerged aquatic vegetation by fishes: testing the roles of food and refuge. Oecologia 77:101-106

Rozas LP, Reed DJ (1993) Nekton use of marsh-surface habitats in Louisiana (USA) deltaic salt marshes undergoing submergence. Mar Ecol Prog Ser 96:147-157

Rozas LP, Zimmerman RJ (2000) Small-scale patterns of nekton use among marsh and adjacent shallow nonvegetated areas of the Galveston Bay Esturay, Texas (USA). Mar Ecol Prog Ser 193:217-239

Rozas LP, McIvor CC, Odum WE (1988) Intertidal rivulets and creekbanks: corridors between tidal creeks and marshes. Mar Ecol Prog Ser 47:303-307 
Sá R, Bexiga C, Vieira L, Veiga P, Erzini K (2002) Diet diversity of the main species of the lower estuary of the Guadiana and the salt marsh of Castro Marim (Algarve, southern Portugal). Littoral 2002: the changing coast. EUROCOAST/EUCC, Porto

Salgado J, Costa MJ, Cabral H, Deegan L (2004a) Comparison of the fish assemblages in tidal salt marsh creeks and in adjoining mudflat areas in the Tejo estuary (Portugal). Cah Biol Mar 45:213-224

Salgado JP, Cabral HN, Costa MJ, Deegan L (2004b) Nekton use of salt marsh creeks in the upper Tejo estuary. Estuaries 27:818-825

Taylor MH, DiMichele L, Leach GJ (1977) Egg stranding in the life cycle of the mummichog, Fundulus heteroclitus. Copeia 1983:719-725

Taylor MH, Leach GJ, DiMichele L, Levitan WM, Jackob WF (1979) Lunar spawning cycle in the mummichog, Fundulus heteroclitus (Pisces: Cyprinodontidae). Copeia 1979:291-297

Teal JM (1962) Energy flow in the salt marsh ecosystem of Georgia. Ecology 43:614-624

Thomas JL (1989) Comparative evaluation of Halodule wrightii Aschers, Spartina alterniflora Loisel and bare sand as nursery habitats for juvenile Callinectes sapidus (Rathbun). MSc dissertation, Texas A\&M University, College Station, TX

Turner RE (1977) Intertidal vegetation and commercial yields of penaeid shrimp. Trans Am Fish Soc 106:411-416

Turner RE (1992) Coastal wetlands and penaeid shrimp habitat. In: Stroud H (eds) Stemming the tide of coastal fish habitat loss. National Coalition for Marine Conservation, Savannah, GA, p 97-104

Vieira L, Bexiga C, Sa R, Veiga P, Erzini K (2002) Abundance and diversity of the fish fauna of the Guadiana River estuary and the Castro Marim salt marsh (SE Portugal). Littoral 2002: the changing coast. EUROCOAST/EUCC, Porto, p 231-234

Vince S, Valiela I, Backus N, Teal M (1976) Predation by the salt marsh killifish Fundulus heteroclitus (L.) in relation to prey size and habitat structure: consequences for prey distribution and abundance. J Exp Mar Biol Ecol 23:255-266

Walters K, Jones E, Etherington L (1996) Experimental studies of predation on metazoans inhabiting Spartina alterniflora stems. J Exp Mar Biol Ecol 195:251-265

Watzin MC, Gosselink JG (1992) The fragile fringe: coastal wetlands of the continental United States. Technical report, Louisiana Sea Grant Program, Louisiana State Uni-

Editorial responsibility: Victor de Jonge (Contributing Editor), Haren, The Netherlands versity, Baton Rouge, Louisiana, US Fish and Wildlife Service, Washington, DC, and the National Oceanic and Athmospheric Administration, Rockville, MD

Webb SR, Kneib RT (2002) Abundance and distribution of juvenile white shrimp Litopenaeus setiferus within a tidal marsh landscape. Mar Ecol Prog Ser 232:213-223

Webb SR, Kneib RT (2004) Individual growth rates and movement of Litopenaeus setiferus in a tidal marsh nursery. Fish Bull 102:376-388

Weisberg SB, Lotrich VA (1982) The importance of an infrequently flooded intertidal marsh surface as an energy source for the mummichog, Fundulus heteroclitus: an experimental approach. Mar Biol 66:307-310

Weisberg SB, Lotrich VA (1986) Food limitation of a Delaware salt marsh population of the mummichog, Fundulus heteroclitus $(\mathrm{L})$. Oecologia 68:168-173

Whitfield AK (1998) Biology and ecology of fishes in southern African estuaries. Ichthyol Monogr JLB Smith Inst Ichthyol 2:1-223

Williams GD, Desmond JS (2001) Restoring assemblages of invertebrates and fishes. In: Zedler JB (eds) Handbook for restoring tidal wetlands. CRC Press, Boca Raton, FL, p 235-269

Williams GD, Zedler JB (1999) Fish assemblage composition in constructed and natural tidal marshes of San Diego Bay: relative influence of channel morphology and restoration history. Estuaries 22:702-716

Wolff WJ, Eeden MN, Lammens E (1979) Primary production and import of particulate organic matter on a salt marsh in the Netherlands. Neth J Sea Res 13:242-255

Ysebaert T, Herman PMJ (2002) Spatial and temporal variation in benthic macrofauna and relationships with environmental variables in an estuarine, intertidal soft-sediment environment. Mar Ecol Prog Ser 244:105-124

Ysebaert T, Meire P, Maes D, Buijs J (1993) The benthic macrofauna along the estuarine gradient of the Schelde estuary. Neth J Aquat Ecol 27:327-341

Ysebaert TP, Meire P, Craeymeersch J, Herman PMJ, Verbeek H (2000) Large scale spatial patterns in estuaries: estuarine macrobenthic communities in the Schelde estuary, NW Europe. In: Macrozoobenthos and waterbirds in the estuarine environment: spatio-temporal patterns at different scales. PhD dissertation, Inst Nature Conservation, Brussels, p 31-51

Zimmerman RJ, Minello TJ (1984) Densities of Penaeus aztecus, Penaues setiferus and other natant macrofauna in a Texas saltmarsh. Estuaries 7:421-433

Submitted: July 10, 2005; Accepted: March 26, 2006

Proofs received from author(s): September 29, 2006 